\title{
Detection of Small Sequence Differences Using Competitive PCR: Molecular Monitoring of Ge- netically Improved, Mercury-Reducing Bacteria
}

BioTechniques 30:142-148(January 2001)

\begin{abstract}
A. Felske, B.V. Pauling, H.F. von Canstein, Y. Li, J. Lauber, J. Buer, and I. Wagner-Döbler National Research Centre for Biotechnology, Braunschweig, Germany
\end{abstract}

\footnotetext{
ABSTRACT

A quantitative PCR approach is presented to detect small genomic sequence differences for molecular quantification of recombinant DNA. The only unique genetic feature of the mercury-reducing, genetically improved Pseudomonas putida KT2442::mer73 available to distinguish it from its native mercury-resistant relatives is the DNA sequence crossing the border of the insertion site of the introduced DNA fragment. The quantification assay is a combination of specific PCR amplification and temperature gradient gel electrophoresis (TGGE). Gene quantification is provided by a competitively co-amplified DNA standard constructed by point mutation PCR. After computing the denaturation behavior of the target DNA stretch, a single base difference was introduced to achieve maximum migration difference in TGGE between the original target DNA and the modified standard without altering the PCR am plification efficiency. This competitive PCR strategy is a highly specific and sensitive way to detect small sequence differences and to monitor recombinant DNA in effluxes of biotechnological plants.
}

\section{INTRODUCTION}

Retaining mercury loads from industrial waste waters (i.e., chloralkali electrolysis plants) by end-of-pipe biofilters is a promising measure for environmental protection (21). This technology is based on a natural mercury resistance mechanism of bacteria capable of reducing the highly toxic $\mathrm{Hg}^{2+}$ ions to elemental mercury (1). A genetically engineered microorganism (GEM), Pseudomonas putida KT2442::mer73, has been constructed in which the mercury and organomercury resistance genes (the merTPAB operon) are expressed constitutively on high levels (8). The operon from the native multiple-resistance plasmid pDU1358 (5) was transferred via a pUT vector (7) into the chromosome of the safety strain $P$. puti$d a$ KT2442. This way of construction circumvented theoretical hazard potential for the environment because (i) original bacterial genes were introduced into common bacteria; (ii) motile genetic elements such as the applied DNA vectors were withdrawn again during genetic engineering; (iii) antibiotic resistance markers for selection were not introduced; and (iv) the mercury resistance genes were introduced into the chromosome and were under the control of a host promoter for constitutively expressed genes. However, this qualitative equality of the introduced genes to the original ones makes it difficult to distinguish such GEMs from native bacteria. The relatively wide distribution of mercury resistance among bacteria excluded the mercury resistance mechanism as a GEM-specific marker.
Also, 16S rRNA approaches to distinguish bacteria are not optimal here because many other mercury-resistant Pseudomonads, including $P$. putida strains, are thriving well in our mercury reduction biocatalyzers (20). The only structural feature unique to the GEM is the nucleotide sequence of the DNA stretch crossing the insertion border from the merTPAB operon to the adjacent original chromosome. The application of PCR primers, in which one is specific for the introduced merTPAB operon and the other for the adjacent $P$. putida chromosome, should yield PCR products of correct length only for the $P$. putida KT2442::mer73 strain.

Because of its high specificity and unsurpassed sensitivity, PCR is the optimal DNA detection tool for many applications. Quantitative PCR can count lowest target numbers, usually by com petitive co-amplification of a standard molecule of known concentration (4). The crucial point is the design of a suitable standard, which, on the one hand, should be highly similar to the target sequence to ensure equal amplification efficiency, but, on the other hand, should yield PCR products easily distinguishable from the target sequence. Here, the temperature gradient gel electrophoresis (TGGE) (12) is applicable because it might separate DNA fragments of the same length by down to one point mutation (11). In contrast, the original competitive PCR approach was based on different length of the sample and the co-amplified standard product (22), which is disputable with regard to a consistent amplification efficiency (18). The combination of quantitative 
PCR and TGGE has already been described for particular variants such as the nPCR/TGGE $(6,15)$, the multiplex RT-PCR/TGGE for relative mRNA quantification (16), or the multiple competitor RT-PCR/TGGE for $16 \mathrm{~S}$ rRNA of bacterial communities (2). Here, we describe the application of competitive PCR and TGGE to monitor the release of recombinant DNA from biocatalyzers inoculated with GEMs.

\section{MATERIALS AND METHODS}

\section{Strain Cultivation and DNA Extraction}

P. putida KT2442::mer73 (8) was cultured in LB medium (trypton $10 \mathrm{~g} / \mathrm{L}$, yeast extract $5 \mathrm{~g} / \mathrm{L}, \mathrm{NaCl} 10 \mathrm{~g} / \mathrm{L}$ ) at $30^{\circ} \mathrm{C}$ for $16 \mathrm{~h}$. The green fluorescent protein (GFP)-labeled variant was constructed by transposon mutagenesis (19) and cultured in the same way. Cells from a 5-mL culture were spun down at $2000 \times g$ for $10 \mathrm{~min}$. The DNA was extracted from the bacteria pellet follow ing a guanidium thiocyanate method (9). DNA concentration was estimated using ethidium bromide (13). DNA samples and defined standards (as $2-\mu \mathrm{L}$ drops) were mixed, each with $2 \mu \mathrm{L}$ ethidium bromide solution $(2 \mu \mathrm{g} / \mathrm{mL}$ in TE buffer), and quantified by fluorescence intensity under UV as digitalized with an E.A.S.Y. charge-coupled device (CCD) camera workstation (Herolab, Wiesloch, Germany) and densitometrically estimated with ImageQuant ${ }^{\mathrm{TM}}$ version 3.3 software (Amersham Pharmacia Biotech, Piscataway, NJ, USA).

\section{Biocatalyzer Setup and Sampling}

Neutralized and aerated chloralkali waste water [type C (20), batch-dependent $\mathrm{Hg}^{2+}$ concentration of 5.1-9.2 $\mathrm{mg} / \mathrm{L}]$ was pumped with $160 \mathrm{~mL} / \mathrm{h}$ into the biocatalyzer (at approximately $25^{\circ} \mathrm{C}$ ) in upflow mode and supplemented with $0.1 \mathrm{~g} / \mathrm{L}$ sucrose and $0.02 \mathrm{~g} / \mathrm{L}$ yeast extract. The catalyzer was a glass column (200-mL volume, 4.8-cm internal diameter) wherein, above a grid, approximately $80 \mathrm{~cm}^{3}$ pumice was placed (core diameter 2.5-3.5 mm; Raab, Neuwied, Germany). Columns and tubing were sterilized by autoclaving $\left(121^{\circ} \mathrm{C}\right.$ for $\left.20 \mathrm{~min}\right)$. All experiments were conducted. Each sampling day, 51 $\mathrm{mL}$ efflux was collected. One milliliter was used for cfu counting where $50 \mu \mathrm{L}$ efflux and serial tenfold dilutions were plated on rich agar medium $(4 \mathrm{~g} / \mathrm{L} \mathrm{su}-$ crose, $2 \mathrm{~g} / \mathrm{L}$ yeast extract, and $15 \mathrm{~g} / \mathrm{L}$ $\mathrm{NaCl}$ ). Three replicates were prepared and checked for growth after a week. The suspended matter of the remaining $50 \mathrm{~mL}$ was harvested by centrifugation at $2000 \times \mathrm{g}$ for $30 \mathrm{~min}$. The pellet was forwarded to DNA extraction and quantitation as described above.

\section{Primer Selection and Standard onstruction}

The simulation of DNA denaturation was computed with the PC software Poland version 1.0 (17), also available as online service (http://www. biophys.uni-duesseldorf.de/POLAND/ poland.html). The default parameters were used for the computation without adjusting to electrophoresis-specific conditions. The concerned DNA stretch (Figure 1) is published in the EMBL database under accession no. AJ251632. The graphs were made with Microsoft $^{\circledR}$ Excel $^{\circledR}$ 97. The following primers were selected: the TGGE primers were RECb (5'-CATCTAGGACACCGTGATC-3') and GC-RECp (5'-CGCCCCCGCCGCCCCGCCGCCCGCG GCCCCGCCCCCGCCCAGCCGTTC CTTGCCTTTAC- $3^{\prime}$ ). The primers for introducing the point mutation $(\mathbf{g})$ were MUTX (5'-CTGTTGCAGACCATGTCATCTAGGACACCGTGATCGGA TCGGCGgAGGCGGCCAGATC-3') and MUTp (5'-CGGGGAACACGCA GATCAGCCGTTCCTTGC-3'). Another primer pair was designed for pro- duction of standardized template DNA solutions with or without mutation, the primers PROb (5'-CAGACCATGTCATCTAGGAC- $\left.3^{\prime}\right)$ and PROp (5'CGCAGATCAGCCGTTCCTTGC-3'). Amplification was performed with a Mastercycler ${ }^{\circledR}$ Gradient (Eppendorf, Hamburg, Germany) using 30 cycles of $94^{\circ} \mathrm{C}$ for $10 \mathrm{~s}, 54^{\circ} \mathrm{C}$ for $20 \mathrm{~s}$, and $68^{\circ} \mathrm{C}$ for $20 \mathrm{~s}$. The PCRs $(20 \mu \mathrm{L})$ contained $10 \mathrm{mM}$ Tris- $\mathrm{HCl}$ (pH 8.3), $50 \mathrm{mM} \mathrm{KCl}$, $3 \mathrm{mM} \mathrm{MgCl} 2,100 \mu \mathrm{M}$ each dATP, dCTP, dGTP, and dTTP, $0.4 \mu \mathrm{M}$ each primer, $0.5 \mathrm{U}$ recombinant Taq DNA polymerase (LifeTechnologies, Paisley, $\mathrm{UK})$, and $1 \mu \mathrm{L}$ template. The PCR with MUT primers on genomic DNA of $P$. putida KT2442::mer73 has been used to introduce the mutation. The PCR with PRO primers has been used to produce standard molecules by re-amplification of the MUT product. These am plifications for standard construction were performed in serial tenfold template DNA dilution to minimize template carry-over.

\section{Competitive PCR and TGGE}

Each competitive PCR experiment consisted of five reactions of decreasing gradients of standard DNA (400 fg and serial threefold dilutions; i.e., $2.7 \times$ $10^{6}, 9 \times 10^{5}, 3 \times 10^{5}, 1 \times 10^{5}, \ldots$ molecules; samples with very low DNA concentration were co-amplified with 40 or $4 \mathrm{fg}$ input and corresponding dilutions). The second competitor was a DNA sample representing $1 \mathrm{~mL}$ catalyzer efflux (i.e., $1 \mu \mathrm{L}$ of $50 \mu \mathrm{L}$ DNA solution per reaction). The five-reactions-mastermixture for a competitive PCR assay was composed for PCRs as described above, but with $5 \mu \mathrm{L}$ template volume

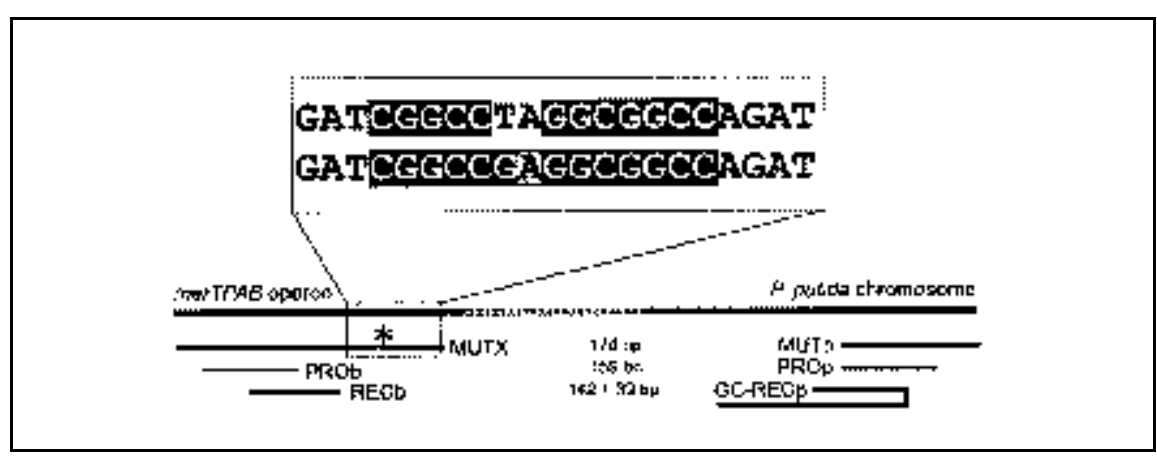

Figure 1. The system of nested primers around the border of the mer $B$ gene and the $P$. putida genome. The base exchange introduced by the MUTX primer will unite the two highlighted GC regions. 
per reaction. The catalyzer efflux DNA was added in $5 \mu \mathrm{L}$ to the five-reactionsmastermixture, and after distribution of the mastermixture to the five reaction tubes $(5 \times 16 \mu \mathrm{L})$, the DNA standards of $4 \mu \mathrm{L}$ per tube were added. The PCR conditions were the same as described above. The Diagen TGGE system (not sold anymore, an advanced device is available from Biometra, Göttingen, Germany) was used for separation of products after PCR $(2 \mu \mathrm{L}$ PCR product input for TGGE). Electrophoresis took place in a $0.8-\mathrm{mm}$ polyacrylamide gel $(6 \% \mathrm{w} / \mathrm{v}$ acrylamide, $0.1 \% \mathrm{w} / \mathrm{v}$ bisacrylamide, $8 \mathrm{M}$ urea, $20 \% \mathrm{v} / \mathrm{v}$ formamide, $2 \%$ v/v glycerol) with $1 \times \mathrm{MN}$ buffer (20 mM MOPS, $10 \mathrm{mM} \mathrm{NaOH}$ ) at a fixed current of $25 \mathrm{~mA}$ (about 480 $\mathrm{V})$ for $2 \mathrm{~h}$. A temperature gradient was built up in electrophoresis direction from $36^{\circ} \mathrm{C}$ to $52^{\circ} \mathrm{C}$. Silver-stained gels (14) were scanned with a GS700 Densitometer (Bio-Rad Laboratories, Hercules, CA, USA) and analyzed with ImageQuant version 3.3 software. In each of the competitive PCR assays, the lanes were selected where the amount of the standard appeared to be most similar to that of the DNA template. Bands showing a bright center (due to overloading) were excluded from analysis (and TGGE repeated with diluted products) to ensure a linear response of measured band intensities to DNA amount. Pixel volumes of the

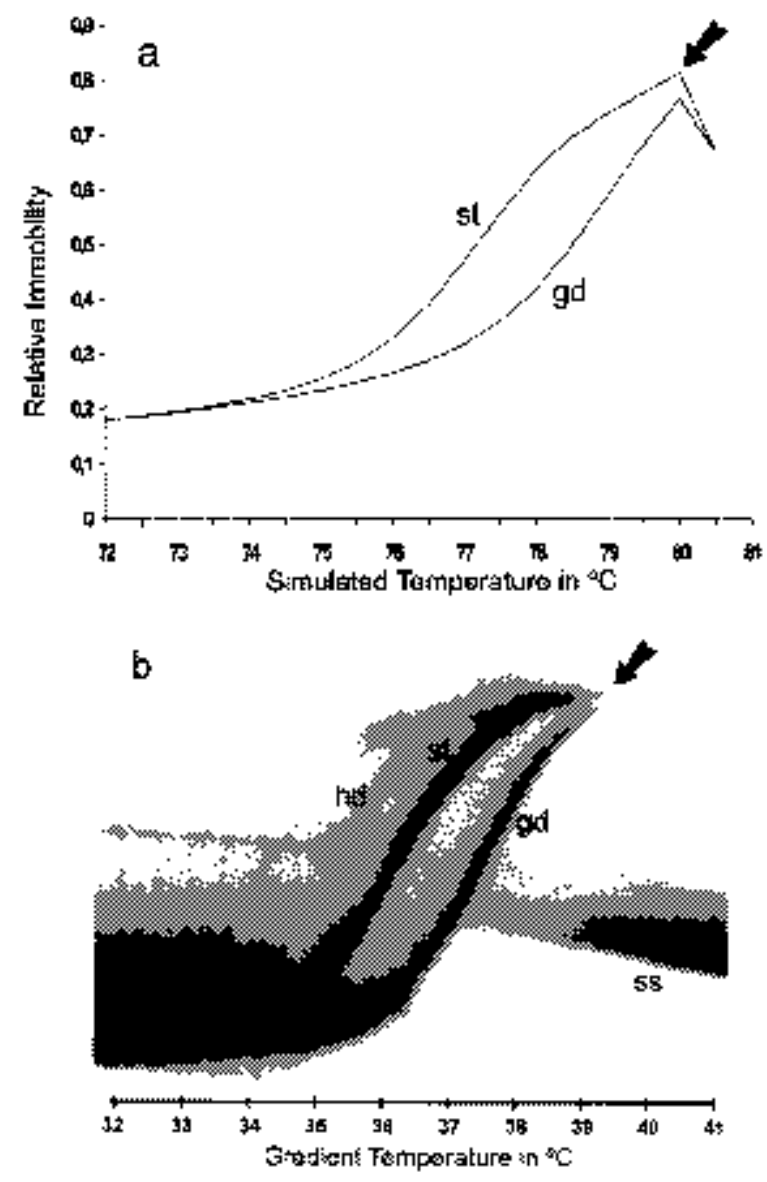

Figure 2. Denaturation behavior of the REC PCR fragment with (st) and without (gd) mutation. (a) The computer simulation shows a clear discrimination of the two fragments in the temperature range from $74^{\circ} \mathrm{C}$ to $80^{\circ} \mathrm{C}$. (b) Perpendicular TGGE shows the predicted discrimination of the fragments, but temperatures were decreased by using urea and formamide in the gel to protect it from drying. The arrow marks the temperature where the molecule melts completely. hd, heteroduplexes; st, standard product; gd, genomic DNA product; ss, single-stranded DNA.

band images were quantified (PV), and the original chromosome amount $(\mathrm{G})$ in the genomic DNA extraction was calculated with these values and the standard molecule amount (ST): $\mathrm{G}=\mathrm{PV}_{\mathrm{G}}$ $\times \mathrm{PV}_{\mathrm{ST}^{-1}}{ }^{-1} \mathrm{ST}$. Since the DNA input represented $1 \mathrm{~mL}$ catalyzer efflux, the GEM chromosome number per milliliter catalyzer efflux could be calculated. Efflux DNA preparation concentrations have been translated into chromosome equivalents with regard to the $P$. putida chromosome size of 6 Mbp (10): 1 ng genomic DNA approximates $1.5 \times 10^{4}$ chromosomes. One standard molecule, a PRO PCR product of $159 \mathrm{bp}$ with $88.4 \mathrm{~kg} / \mathrm{mol}$, is equivalent to one GEM chromosome (400 fg standard DNA $=2.7 \times 10^{6}$ GEM chromosome equivalents).

\section{Perpendicular TGGE}

The sample for perpendicular TGGE was a mixture of $100 \mu \mathrm{L}$ REC PCR product from the modified standard and $100 \mu \mathrm{L}$ REC PCR product from the $P$. putida KT2442::mer73 genomic DNA applied along a slot covering almost the whole gel width. TGGE was done for 15 min without temperature gradient $\left(30^{\circ} \mathrm{C}\right)$, then interrupted to set up a $30^{\circ} \mathrm{C}-59^{\circ} \mathrm{C}$ gradient in a perpendicular direction to the electrophoresis and was continued for another $75 \mathrm{~min}$ (other TGGE parameters as above).

\section{Kinetic PCR}

Amplification kinetics with REC primers were detected with the $\mathrm{Ge}$ neAmp ${ }^{\circledR} 5700$ sequence detection system (Applied Biosystems, Foster City, CA, USA). Samples were PRO PCR products from the modified standard and from the $P$. putida KT2442::mer73 genomic DNA in serial tenfold dilutions ( $1 \mathrm{fg}$ to $1 \mathrm{pg}$ template input) analyzed with the SYBR ${ }^{\circledR}$ Green PCR Core Reagents kit (Applied Biosystems). The amount of PCR product has been measured after each cycle, and with Excel 97, the slopes of the achieved amplification kinetics were calculated by linear regression (correlation coefficient $r^{2}>0.999$ ). From this slope the multiplication factor $\mathrm{m}$ per cycle was estimated (formula: $c_{n}=m c_{n-1}$; $\mathrm{c}=$ DNA yield; $\mathrm{n}=$ cycle number). 


\section{RESULTS AND DISCUSSION}

\section{Competitive PCR Target Site and TGGE}

Competitive PCR requires a concentration standard that is easily distinguishable from the target DNA. TGGE separates PCR products by its denaturation behavior along a temperature gradient. The disproportionate DNA double-strand stability, caused by the higher stability of GC pairs compared to AT pairs, must be considered for optimal TGGE performance. A GC-rich DNA stretch may be a good target to manipulate DNA double-strand stability by base exchanges. In the border region of the mer $\mathrm{B}$ gene and the adjacent chromosome, we identified a 142-bp DNA stretch that included two GC-rich regions of pronounced double-strand stability, which were only separated by two TA pairs (Figure 1) and could be combined by replacing one of the TA pairs by a GC pair. The TGGE primer target sites were selected upstream (primer RECb, within the mer $\mathrm{B}$ gene) and downstream (primer GC-RECp, within the $P$. putida chromosome) of

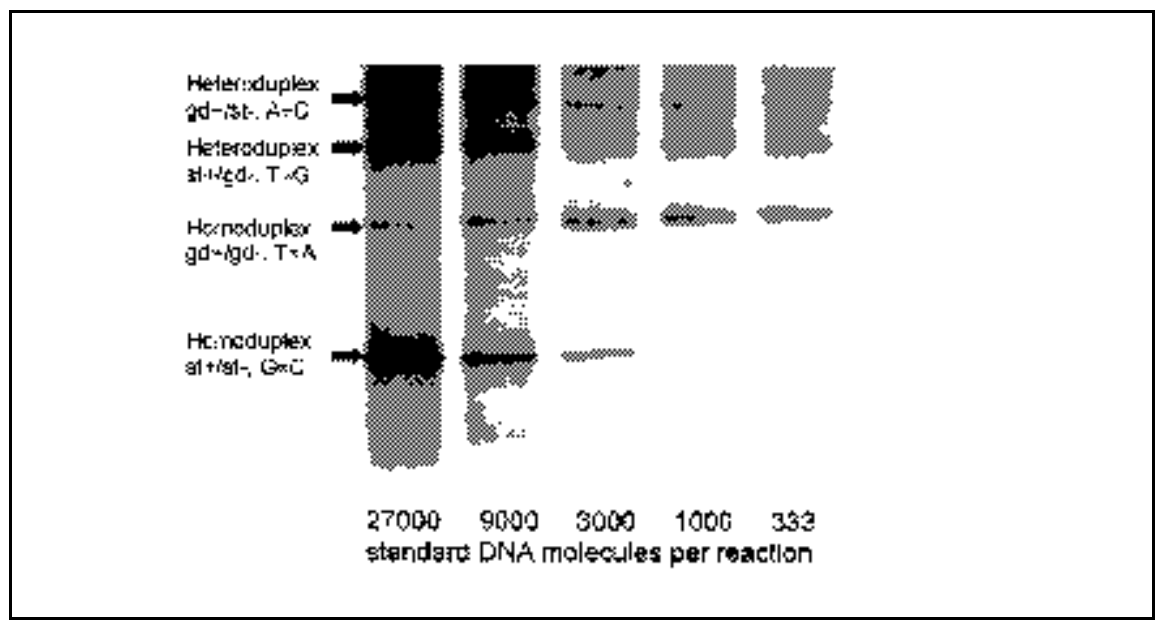

Figure 3. Competitive PCR assay with catalyzer efflux DNA from day 52 separated on TGGE. The first lane contained $4 \mathrm{fg}$ standard DNA (approximately 27000 molecules). In this assay, the second and the third lane were used for densitometric analysis to calculate the number of merTPAB operons in the competitive PCRs. hd, heteroduplexes; st, standard product; gd, genomic DNA product. 


\section{Research Report}

the GC-rich regions (Figure 1). The simulation of the REC PCR product migration speed at different temperatures and the experimental confirmation via perpendicular TGGE demonstrated the drastically changed denaturation behavior conditions (Figure 2), resulting in distinct TGGE bands of the com petitive PCRs (Figure 3 ). The high tem peratures required to force the melting (Figure $2 \mathrm{a}$ ) could be reduced by $40^{\circ} \mathrm{C}$ by using the denaturing gel ingredients urea and formamide (Figure $2 b$ ) to protect the gel from drying (3).

\section{Competitive PCR Standard Construction}

The point mutation was introduced 10 bp in front of the RECb $3^{\prime}$ end (Figure 1). Since the mutation-introducing MUTX primer was covering this area including the RECb sequence, it was possible to re-amplify the product of the MUT primer pair with the REC or PRO primers. The amplification of serial dilutions of genomic GEM-DNA with the MUT primer pair succeeded with a DNA input of as low as $200 \mathrm{fg}$ (approximately 30 chromosomes, data not shown). This MUT PCR product again could be re-amplified with the PRO primers down to a template dilution of $10^{-7}(1 \mu \mathrm{L}$ template in $20 \mu \mathrm{L}$ reaction volume). With $200 \mathrm{fmol} / \mu \mathrm{L} \mathrm{nu}-$ cleotide input, the PCRs were theoretically able to produce approximately $2 \times 10^{8}$ molecules $/ \mu \mathrm{L}$. Thus, the routine standard DNA production with the PRO primers and the MUT PCR product as DNA template $\left(10^{-6}\right.$ dilution) was based on a maximum of 200 MUT template molecules with virtually no genomic DNA remains $(1.5 \times$ $10^{-7}$ chromosomes $\left./ \mu \mathrm{L}\right)$.

\section{PCR Optimization}

All three primer pairs (REC, MUT, and $\mathrm{PRO}$ ) produced the correct amplification fragment with reproducibly high specificity and efficiency. Annealing temperatures from $45^{\circ} \mathrm{C}$ to $60^{\circ} \mathrm{C}$ yielded no significant change of PCR sensitivity or specificity (optimum at approximately $54^{\circ} \mathrm{C}$ ). Above $60^{\circ} \mathrm{C}$ annealing temperature, the product yield started to decline. Although no particular problems of PCR specificity or sensitivity

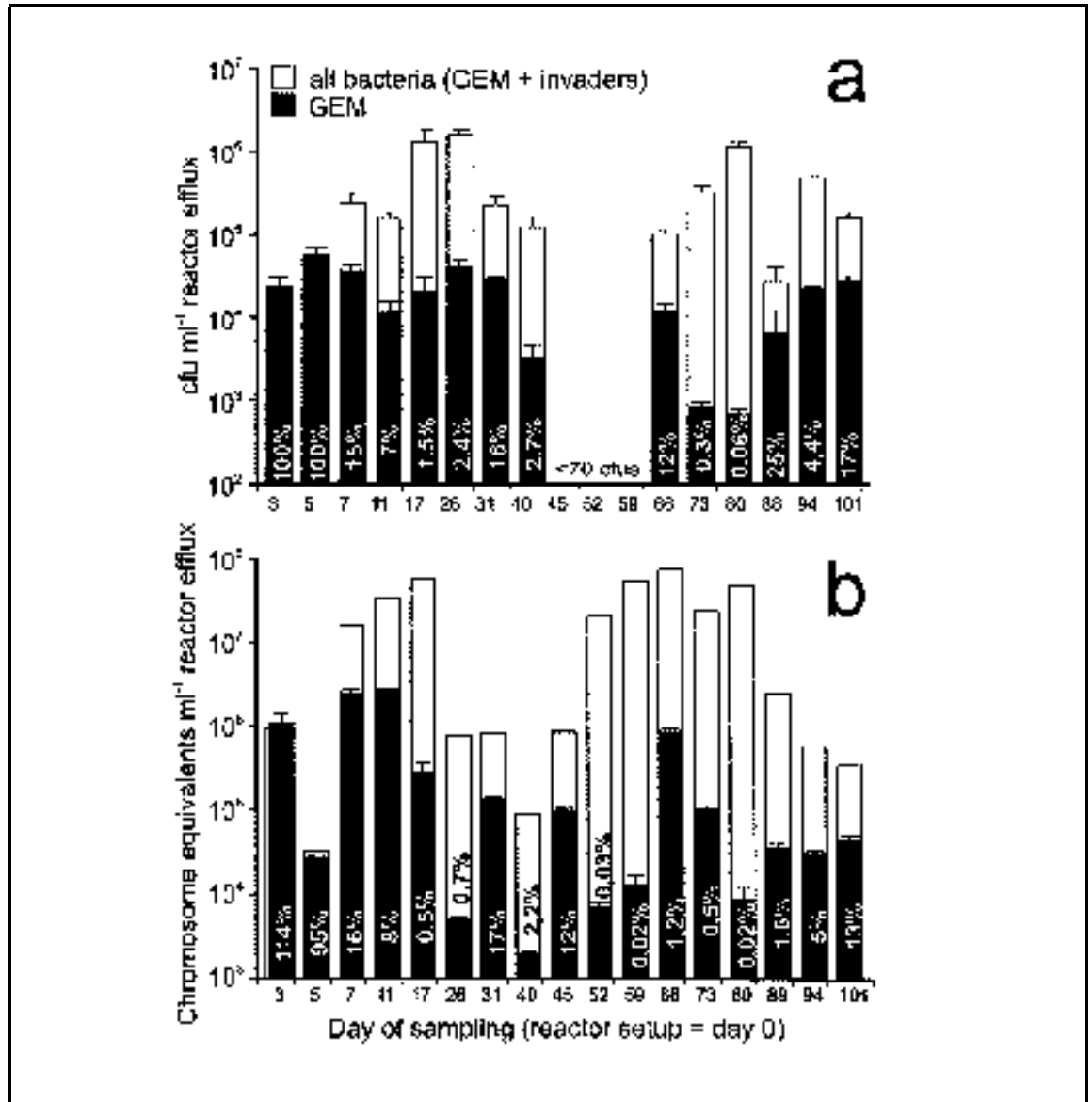

Figure 4. Comparison of the GEM and invading bacteria in the catalyzer efflux by cfu counts and DNA quantification. (a) The cfu counts of all bacteria (white columns), only the fluorescent cfu counts of the GFP-labeled GEMs (black columns), and the percentage of GEMs (all bacterial cfus $=100 \%$ ). (b) The total yield of bacterial DNA extracted from catalyzer efflux samples (white columns) given as chromosomal equivalents ( 1 equivalent $=6.7 \mathrm{fg}$ DNA), only the GEM chromosomal equivalents ( 1 equivalent $=1$ merTPAB operon) as quantified by the competitive PCR, and the percentage of GEM chromosomal equivalents (total DNA $=100 \%)$. The small bars indicate the standard deviation $(n=3)$.

could be observed, the difference in denaturation behavior of the modified standard and the original sequence might have caused a sequence-specific amplification bias. This has been investigated with kinetic PCR. Here, a PRO PCR product from native genomic DNA and the standard (PRO PCR product with point mutation) were separately re-amplified with REC primers. After each PCR cycle, the product concentration was measured to monitor the exponential product increase. In both cases, we found an amplification factor of $\mathrm{m}=$ 1.759(6). The reduced denaturation capability of the standard DNA did not noticeably influence the amplification rate of approximately $76 \%$ of all template molecules being completely copied during each cycle.

\section{Monitoring of Recombinant DNA Efflux from a Small-Scale Biocatalyzer}

A biocatalyzer inoculated with a GFP-labeled $P$. putida KT2442:: mer73::gfp11 was observed for 100 days to compare the competitive PCR method with cfu counts (Figure 4). The count of GFP-labeled colonies under UV light showed a broad variation over three orders of magnitude across the whole period. Total cfu counts and efflux DNA extraction yields also varied over several magnitudes because of an irregular and unpredictable release of biomass from the catalyzer. Moreover, the efflux DNA extraction yields indicated up to two magnitudes more bacteria than detectable on the cfu count 
plates. It appears reasonable that the collected bacteria are not in good condition because mainly old biofilm fragments were flushed out of the catalyzer. The comparison of merTPAB numbers to the total DNA extraction yield correlated well to the ratio of total cfu to the GFP-labeled GEM cfu. The results showed that the GFP-labeled GEM (initially at $100 \%$ ) has rapidly been challenged by mercury-resistant contaminants from the nonsterile wastewater input. Apparently, the fitness of $P$. putida KT2442::mer73::gfp11 was considerably reduced by the metabolic burden of GFP production and accumulation. Thus, it was struggling against different environmental bacteria and did not succeed to establish itself as the dominant catalyzer strain. Independent from the variable GEM competitiveness, the mercury retention rate, also based on the activity of the intruders, reached a respectable $95 \%$.

\section{CONCLUSIONS}

PCR-based approaches are the primary choice to overcome difficulties to identify GEMs with additional genes because the interrupted original genom ic DNA sequence and its new insert provide an arrangement of nucleotide sequences, which certainly is unique. The TGGE-based approach can be a detection method of universal applicability to competitive PCR approaches. The construction of the standard consists of a simple sequence of nested PCRs to introduce a point mutation. Our case demonstrates a much higher release of intact DNA than of viable cells. Hence, a genetic, culture-independent detection method, such as the one described here, is often preferable. This method also bears the possibility to recover the recombinant DNA from dead $P$. putida KT2442::mer73 in other organisms to trace transformation events. Such events are considered to be rather unlikely, but their investigation is an essential part of risk assessment of genetically engineered organisms. The approach presented here will serve to reveal the impact of GEM efflux from biocatalyzers on the environment in terms of bacterial community composition and transformation with recombinant DNA.

\section{ACKNOWLEDGMENTS}

This work was granted by the European Community's projects BIO4-CT98-0168 and LIFE97 ENV/D/000463. We would like to thank Patrizia Gatzlaff for technical assistance.

\section{REFERENCES}

1.Brunke, M., W.-D. Deckwer, A. Frischmuth, J.M. Horn, H. Lünsdorf, M. Rohde, M. Röhricht, K.N. Timmis and P. Weppen. 1993. Microbial retention of mercury from waste streams in a laboratory column containing merA gene bacteria. FEMS Microb. Rev. 11:145-152.

2.Felske, A., A.D.L. Akkermans and W.M. de Vos. 1998. Quantification of 16S rRNAs in complex bacterial communities by multiple competitive reverse transcription-PCR in tem perature gradient gel electrophoresis fingerprints. Appl. Environ. Microbiol. 64:45814587.

3.Felske, A., A. Wolterink, R. van Lis, W.M. de Vos and A.D.L. Akkermans. 1999. Searching for predominant soil bacteria: $16 \mathrm{~S}$ rDNA cloning versus strain cultivation. FEMS Microbiol. Ecol. 30:137-145.

4.Freeman, W.M., S.J. Walker and K.E. Vrana. 1999. Quantitative RT-PCR: pitfalls and potential. BioTechniques 26:112-125.

5.Griffin, H.G., T.J. Foster, S. Silver and T.K. Misra. 1987. Cloning and DNA sequence of the mercuric- and organomercurial-resistance determinants of plasmid pDU1358. Proc. Natl. Acad. Sci. USA 84:3112-3116.

6.Henco, K. and M. Heibey. 1990. Quantitative PCR: the determination of template copy numbers by temperature gradient gel electrophoresis (TGGE). Nucleic Acids Res. 18:6733-6734.

7.Herrero, M., V. de Lorenzo and K.N. Tim mis. 1990. Transposon vectors containing non-antibiotic resistance selection markers for cloning and stable chromosomal insertion of foreign genes in Gram-negative bacteria. J. Bacteriol. 172:6557-6567.

8.Horn, J.M., M. Brunke, W.-D. Deckwer and K.N. Timmis. 1994. Pseudomonas putida strains which constitutively overexpress mercury resistance for biodetoxification of organomercurial pollutants. Appl. Environ. Microbiol. 60:357-362.

9.Pitcher, D.G., N.A. Saunders and R.J. Owen. 1989. Rapid extraction of bacterial genomic DNA with guanidium thiocyanate. Lett. Appl. Microbiol. 8:151-156.

10.Ramos-Díaz, M.A. and J.L. Ramos. 1998. Combined physical and genetic map of the Pseudomonas putida KT2440 chromosome. J. Bacteriol. 180:6352-6363.

11.Ringel, M.D., W.F. Schwindinger, M. Saji, M.A. Zeiger and M.A. Levine. 1998. Determination of transgene copy number and expression level using denaturing gradient gel electrophoresis. BioTechniques 24:126-131.

12.Rosenbaum, V. and D. Riesner. 1987. Tem perature-gradient gel electrophoresis-ther- modynamic analysis of nucleic acids and proteins in purified form and in cellular extracts. Biophys. Chem. 26:235-246.

13.Sambrook, J., E.F. Fritsch and T. Maniatis. 1989. Saran wrap method, appendix E6. In Molecular Cloning: A Laboratory Manual, 2nd ed. CSH Laboratory Press, Cold Spring Harbor, NY.

14.Sanguinetti, C.J., E. Dias Neto and A.J.G. Simpson. 1994. Rapid silver staining and recovery of PCR products separated on polyacrylamide gels. BioTechniques 17:915-919.

15.Schäfer, P., R.W. Braun, K. Möhring, K. Henco, J. Kang, T. Wendland, and J.E. Kühn. 1993. Quantitative determination of human cytomegalovirus target sequences in peripheral blood leukocytes by nested polymerase chain reaction and temperature gradient gel electrophoresis. J. Gen. Virol. 74:2699-2707.

16.Sölch, J.P. and G.J. Arnold. 1996. Multiplex reverse transcription polymerase chain reaction combined with temperature gradient gel electrophoresis as a tool for the normalized quantitation of intrinsic factor mRNA. Electrophoresis 17:30-39.

17.Steger, G. 1994. Thermal denaturation of double-stranded nucleic acids: prediction of temperatures critical for gradient gel electrophoresis and polymerase chain reaction. Nucleic Acids Res. 22:2760-2768.

18.Stolovitzky, G. and G. Cecchi. 1996. Efficiency of DNA replication in the polymerase chain reaction. Proc. Natl. Acad. Sci. USA 93:12947-12952.

19.Suarez, A., A. Güttler, M. Strätz, L.H. Staendner, K.N. Timmis and C.A. Guzmán. 1997. Green fluorescent protein-based reporter systems for genetic analysis of bacteria including monocopy applications. Gene 196:69-74.

20.von Canstein, H., Y. Li, K.N. Timmis, W.-D. Deckwer and I. Wagner-Döbler. 1999. Removal of mercury from chloralkali electrolysis wastewater by a mercury-resistant Pseudomonas putida strain. Appl. Environ. Microbiol. 65:5279-5284.

21.Wagner-Döbler, I. 1999. Mikroorganismen reinigen Abwasser von giftigen Quecksilberverbindungen. Biologie in unserer Zeit 29:44-53.

22.Wang, A.M., M.V. Doyle, and D.F. Mark. 1989. Quantitation of mRNA by the polymerase chain reaction. Proc. Natl. Acad. Sci. USA 86:9717-9721.

Received 13 March 2000; accepted 2 August 2000.

\author{
Address correspondence to: \\ Dr. Andreas Felske \\ GBF (National Research Centre \\ for Biotechnology) Division of Microbiology \\ Mascheroder Weg 1 \\ D-38124 Braunschweig, Germany \\ e-mail: afe@gbf.de
}

